\title{
EDUCATIONAL AND METHODOLOGICAL SUPPORT FOR EFL TEACHING IN BELARUSIAN UNIVERSITIES
}

\author{
P.A. Gubich*, K.O. Klimut \\ Mogilev State A. Kuleshov University, Mogilev, Belarus \\ Corresponding author*: gubichpolina@gmail.com
}

\begin{abstract}
The article deals with the relevant problem of educational and methodological support for EFL teaching for students of language specialties in Belarusian universities. The article presents an overview of the methodological textbooks covering the content of the discipline "First Foreign Language" for the specialty 1-21 0506 "Romance and Germanic philology", prepared by the lecturers of the Department of Theoretical and Applied Linguistics of Mogilev State A. Kuleshov University. The article describes the structural features of educational and methodological textbooks, their thematic and informative content. Various types of exercises (language exercises, conditional speech exercises, speech exercises) are reviewed. Examples of exercises used in different sections (such as Topical Vocabulary, Lead-in, Focus on Reading, Focus on Vocabulary, Focus on Idioms, Focus on Listening, Focus on Speaking, Focus on Writing, Project, etc.) are provided. The article draws conclusions about the importance of adapting EFL textbooks for students of language specialties in Belarusian universities in accordance with the communicative approach and programme documentation.
\end{abstract}

Keywords: EFL teaching, EFL textbook, English, first foreign language, Belarusian higher education.

\section{Introduction}

In view of the intensive spread of English as a language of intercultural communication, developing competitive and suitable EFL textbooks has become one of the primary goals for EFL teachers and linguists worldwide. The growing interest in EFL learning demands substantial teachware. Modern EFL textbooks should be aimed both at consolidating language skills and at satisfying students' interests. According to Tikhonova and Raitskaya, "there is a growing gap between academic and student understandings of education quality" [1;5]. It means that the aims of a teacher and those of a student usually differ. Ibna Seraj and Habil single out three different factors impacting EFL learners: those of environmental, psychological and linguistic character. The linguistic factors are related to "learner's lack of language knowledge, accuracy, fluency and low vocabulary levels" [2;237]. A lack of teaching resources along with the lack of authentic materials is also an important issue: to meet the needs of both teachers and students, sufficient textbooks must be provided. It is of great importance to develop a textbook that can cover all the aspects of the language and be relevant for the learners belonging to a specific linguoculture. This problem is being solved worldwide, including Belarus.

The development of textbooks is one of the most relevant problems in EFL teaching in Belarusian Higher Educational Institutions, including a popular specialty "Romance and Germanic philology". The specificity of the Belarusian situation, as well as that of the other post-Soviet countries, lies in the fact that programme documentation has been developed in the way that only partly correlates with communicative approach based textbooks used in EFL teaching worldwide. In Belarus, these textbooks are widely used in teaching a foreign language at language courses, however, in the university education system there exists an urgent need to develop new textbooks that would be based on a communicative approach and at the same time would correspond to Belarusian program documentation and satisfy the need of EFL students.

As an attempt to meet this challenge, the lecturers of the Department of Theoretical and Applied Linguistics of Mogilev State A. Kuleshov University (Mogilev, Belarus) worked out educational and methodological support for the discipline "First Foreign Language", specialty 1-21 0506 "Romance and Germanic philology".

The academic subject "First Foreign Language" is an integral part of lifelong language learning in the principal subjects aimed at specialist training in the field of English. The objectives of the subject include improvement of reading technique, development of reading literacy and development of listening skills in various communicative areas; strengthening the capacity to pursue communicative intention in accordance with the linguistic norms of the functional area and the communicative situation; development of students' solid skills and abilities to use grammatical structures in oral and written communication.

It seems obvious that one of the ways to fulfill the goals set is to create high-quality educational and methodological support intended to develop a necessary professional competence, while being 
tailored to individual characteristics of students and aimed at training skilled professionals in the sphere of English. Therefore, during the period from 2015 to 2021, twenty one textbooks were developed by the staff of the Department, three of which were approved by the Ministry of Education of the Republic of Belarus [3, 4, 5], and eighteen - by the Methodological Association of Foreign Language Teachers of Higher Education Institutions of the Republic of Belarus [6, 7, 8, 9, 10, 11, 12, 13, 14, 15, 16, 17, 18, 19, $20,21,22,23]$. The consideration of these textbooks in accordance with the aspects they cover is given further.

\section{Materials and methods}

\section{Development of Pronunciation Skills}

"First Foreign Language: Level 1: Practical Phonetics: Introductory Course" [22] is a textbook approved by the Methodological Association of Foreign Language Teachers and focused on the forming of students' basic knowledge of the English phonetic system and the rules for the functioning of phonetic units in speech, as well as the skills and abilities of the modern English pronunciation norm. It consists of fourteen units which include theoretical material and exercises for the formation and improvement of students' pronunciation skills. All units are structured by sections. The Key words section includes basic concepts on the topic of the lesson. The Question for discussion section provides a list of theoretical questions that will be discussed in the Theoretical background section. The Self-check section contains a list of questions to check the acquisition of theoretical material. The Sound drills section presents practical tasks for training and consolidating the knowledge gained from separate sounds or sounds combinations. The English rhythm practice section includes tasks for practicing English rhythm. The Intonation exercises section presents exercises aimed at training and consolidating the knowledge of the prosodic organization of the English phrase. Some units also include the Speech exercises section. The textbook can be used both for classroom work and for students' independent work.

The Department of Theoretical and Applied Linguistics of Mogilev State A. Kuleshov University are currently working on a new textbook "Practical Phonetics of the First Foreign Language". The teaching materials of this textbook are aimed at identifying and eliminating phonetic mistakes encountered in students' speech, as well as preventing typical mistakes for Belarusian and Russian speakers who study English as the first foreign language. As a rule, students studying at the faculty of foreign languages already possess some pronunciation skills, but they are not always correct. The main task of the correctional course is to eliminate the wrong phonetic skills, which in turn will prevent the formation of a stable abnormal accent, and, if possible, will bring students' pronunciation closer to the modern British pronunciation standard.

\section{Development of Grammar Skills}

The study of English grammar is of particular importance for the students majoring in English. Therefore, three grammar textbooks have been developed: "Practical English Grammar: Morphology" [5] approved by the Ministry of Education, "Practical English Grammar: Elementary Level" [18] and "Practical English Grammar: Verbals" [16] approved by the Methodological Association of Foreign Language Teachers of Higher Education Institutions of the Republic of Belarus.

The textbook "Practical English Grammar: Elementary Level" [18] is oriented towards the elementary level and includes introductory information on grammatical topics such as "The Verb to be", "Construction There + To be", "The Active Voice", "The Passive Voice", "The Sequence of Tenses and the Reported Speech" and "Irregular Verbs". Each topical part of the textbook includes a rule section and exercises on the given topic.

The textbook "Practical English Grammar: Morphology" [5] consists of seven parts, each of which includes general rules for the use of various parts of English speech ("The Noun", "The Article", "The Adjective", "The Adverb", "The Pronoun", "The Numeral" and "The Verb") and exercises that contribute to the effective acquisition of theoretical knowledge and formation of skills and proficiency of grammatically correct English speech. Each thematic part focuses on a specific grammatical phenomenon. The tasks differ in variety and degree of difficulty. The content of the exercises is determined by the purpose to provide the most effective assimilation, formation and consolidation of skills and proficiency of grammatically correct English speech. Each part contains different types of exercises.

"Practical English Grammar: Verbals" [16] is a continuation of the textbook "Practical English Grammar: Morphology". The textbook contains about 1500 tests on such topics as "The Infinitive", "The 
Gerund", "Participle I" and "Participle II". The book can be used in the educational process both for students' self-preparation and during the class work, as well as for monitoring students' knowledge in the field of non-finite forms of the verb. The textbook includes guidance for students' independent work with the proposed language material outside the classroom.

\section{Development of Speaking and Writing Skills}

The most intensive work is carried out in the direction of developing students' speaking and writing skills as the key competence in the view of the communicative approach. Therefore, the largest number of textbooks has been developed in this aspect. The example of such textbooks is "English: Developing Speaking and Writing Skills" in two parts [3, 4], approved by the Ministry of Education of the Republic of Belarus. These textbooks have a similar structure and reveal the main thematic parts that are included in the training programme for a specialist with the knowledge of English as the first foreign language.

Part I of the textbook "English: Developing Speaking and Writing Skills" consists of three sections each of which includes 15 units: 1) "Jobs" ("Professional Activity in the Life of Society", "Job Hunting", "Professional life and human relations", "Career prospects for English learners"), 2) "Healthcare" ("Human body: Strong and Weak", "Medical Service", "Treatment: Modern Methods"), and 3) " $21^{\text {st }}$ Century Diseases" ("Incurable Diseases of Modern Times", "Big City Diseases", " $21^{\text {st }}$ Century Addictions").

Part II contains two sections including 15 units each: 1) "Sport" (which includes such topics as "Sport in Our Life", "Sport Around the World", "Problems and Challenges of Modern Sport"), and 2) "World Map. City Life" ("National Diversity", "Across the Universe").

Each part includes exercises that contribute to the formation and consolidation of skills and abilities of the English language proficiency on the corresponding topic. All the exercises are structured by sections.

Each section contains different types of exercises: language exercises, conditional speech exercises and speech exercises. Language exercises are aimed at analysing, differentiating, reproducing and training phonetic, lexical and grammatical skills. Conditional speech exercises are situational. These tasks are aimed at practicing language material in conditional educational communication that simulates natural communication. Speech exercises are aimed at the development of speaking, listening, reading and writing skills in situations close to real-life conditions and are mostly focused on stimulating spontaneous speech.

The Lead-in section contains introductory information on the topic of the lesson. Practices that are presented in this section are aimed at motivating students and arousing their interest in the topic, therefore they are multivarious, including questions and answers exercises, quizzes, personal tests, exercises on picture description, commenting on quotations, etc. Such exercises help students to delve into the given topic, while expressing their own ideas and sharing their experience.

The Topical Vocabulary section contains active vocabulary to train and fix in the Focus on vocabulary and Focus on idioms sections. The exercises in these sections include matching words/word combinations/idioms and their definitions, explaining the meaning of the words/word combinations/idioms and using them in the sentences of your own, odd-one-out tasks, word building exercises including word-category tables and word families, providing synonyms and antonyms, fill-inthe-gaps exercises, as well as sentence translation activities. Though the last-mentioned type of exercises is usually neglected in most communicative approach based textbooks, we believe that translation is an essential aspect in EFL teaching, helping students to compare their native language with the foreign one, which contributes to avoiding irrelevant grammatical and lexical loan translations and reveals some typical mistakes in oral and written speech. Furthermore, such tasks develop the ability to construct sentences in English using appropriate grammar structures and new vocabulary and thus show their effectiveness in developing students' communicative ability (see a relevant study by Adil [24]).

The Focus on reading section includes exercises for working with text, which are focused on practicing different types of reading, i. e. skimming, scanning, intensive and extensive reading. As is well known, the process of reading is divided into three stages: pre-reading, while-reading and post-reading. In the described textbooks, the pre-reading stage is presented by anticipation exercises such as examining the pictures and captions, analyzing the title of the text, reading the first paragraph and guessing the topic of the text, keywords exercises, etc. The following activities are common for the while-reading stage: identifying topic sentences, distinguishing between general and specific ideas, answering a short quiz, matching or making up headings, compiling a plan, etc. The exercises on the post-reading stage are 
usually aimed at critical analyzing of the text and include True or False exercises, analyzing the message of the text, correcting mistakes, filling the gaps, summarizing, matching exercises, etc.

Exercises in the Focus on speaking section vary from language and speech exercises to conditional speech exercises. The two devices that help in making up communicative activities are information-gaps and opinion-gaps. The former encourages students to exchange information to find a solution, while the latter lets students share their ideas, opinions and feelings about the experience they have. This section includes questions and answers activities (interviews, guessing games and questioning activities), discussions and decisions exercises (ranking exercises, discussion games, thinking strategies and problem-solving activities), stories and scenes (role plays and simulations). Practices that develop linguistic guessing and speech compatibility are also used in the textbooks.

The section Project includes creative tasks that can be modified by the teacher and offered to students as a home task. Students can be asked to work individually or in small groups and invent their own game, draw a poster, make a PowerPoint or Prezi presentation, shoot a video, create an advertisement or role-play a particular situation.

In the Focus on writing section, students are offered to write letters, e-mails, opinion and argumentative essays, articles and reports according to the B2-level of the Common European Framework of References for Languages (CEFR). These exercises are also developed in a creative manner, for example: "Imagine the world without jobs. What would it look like? Would it be better if people didn't have to work? Would there still be those who are truly eager to work? Express your ideas and thoughts in an essay (160-190 words)" [3;33]; "Write a letter of invitation to a person from another country. The main purpose of the letter is to make them be interested in Belarus and come to visit it. Be creative, sky is your limit!" [4;114]; "Write an article to a student newspaper "Why so many people (don't) enjoy learning foreign languages" (160-190 words)" [3;103].

The textbook also includes a Focus on listening section aimed at improving listening skills. These exercises allow students to listen to English speech outside the in-class learning. The pre-listening stage is presented by such tasks as analyzing the title of the text, mind maps, discussion questions, gap fills, etc. The while-listening stage exercises are Listen \& Describe, True or False, multiple choice exercises. At the post-listening stage a range of vocabulary and speaking practices are proposed.

The major advantage of the textbooks is the use of modern-day thought-provoking authentic texts. The proposed texts and audio materials broaden students' general knowledge and serve as an incentive for group discussion. In addition, the textbooks widely use the techniques of the communicative language teaching. Assignments and exercises are of a communicative nature and are focused on the formation of speaking and writing skills in various communicative situations. The value of the textbooks also lies in creative tasks contributing not only to acquiring competence in speaking and writing but also to the enlargement of students' imaginative and critical thinking, which is one of the main aims of the communicative approach [25].

\section{Results}

\section{Consolidation of skills}

In 2020-2021, in addition to the textbooks aimed at the development of speaking and writing skills, three collections of tests were published [13, 14, 15]. Each collection includes at least 130 multiple-choice questions helping to practice and consolidate the vocabulary studied. At the end of each manual, answers to the tasks are presented, allowing students to check the achievement of the covered material independently.

The textbook "English Speech Practice. Level 1. Lexical Meaning: Choosing the Right Word" [13] consists of six units: "Family", "Personality. Character and Appearance", "Food and Meals. Cooking", "Accommodation", "Jobs" and "Leisure. Hobbies. Interests". "English Speech Practice. Level 2. Lexical Meaning: Choosing the Right Word" [14] contains five units: "Education", "City Life", "The Map of the World", "Shopping" and "Multiple Service". The $3^{\text {rd }}$ part of the three collections "English Speech Practice. Level 3. Lexical Meaning: Choosing the Right Word" [15] is made up of five units: "Professional Life. Career Prospects for Language Students", "Human Body", "Diseases and Their Treatment", "Sport" and "Travelling and Holiday Making". Each unit contains 9-13 exercises made up by $10-30$ questions.

Tests for alternative $(a, b)$ and multiple $(a, b, c$ or $a, b, c, d)$ choices are offered. Each unit contains assignments aimed at developing students' ability to choose the correct word among the words that are close in meaning; to select the antonym; to detect a stylistic mistake in the usage of the word in 
context; to detect a spelling mistake or to define the compatibility/incompatibility of lexical units and use these units in phrases and set expressions.

\section{Discussion}

\section{Linguistic research}

To assist students' research in linguistics, two textbooks have been published: "Yearly Paper in Linguistics" [19] and "The Etymology and History of English Proverbs" [20]. Both textbooks are approved by the Methodological Association of Foreign Language Teachers of Higher Education Institutions of the Republic of Belarus. Students can use these textbooks while working on their own research in the field of academic linguistic disciplines, including "History of the English Language", "Lexicology of the English Language", "First Foreign Language", etc. as well as a helping tool in the preparation of yearly and diploma papers.

The textbook "Yearly Paper in Linguistics" contains methodical guidelines for the writing of a yearly paper in linguistics in the subject areas of English phraseology, paremiology and aphoristics, the study of semantic and structural features, functional and stylistic characteristics of the main phraseological unities of the English language in its historical dynamics and in its contemporary state, in typological comparison with the native (Belarusian or Russian) language, as well as in the aspect of translation from English into the native language or vice versa.

The origin, etymology, history of use and historical variants of proverbs common in modern English, which originate from literary texts or have long been used in literary texts, are described in the textbook "The Etymology and History of English Proverbs" [20].

\section{Conclusion}

The development of textbooks is one of the most challenging aspects in training a specialist with the knowledge of a foreign language. EFL textbooks should be constantly updated to meet the requirements of the modern world and satisfy the interest and needs of the students. They should include culturally authentic and responsive texts as well as exercises aimed at the development of all the competences and abilities related to capturing a foreign language, including such skills as competently expressing one's thoughts in oral and written forms and freely understanding oral dialogical and monologue speech. Concurrently, these textbooks should meet the requirements of the programme documentation developed for a certain specialty.

The work carried out at the Department of Theoretical and Applied Linguistics of Mogilev State A. Kuleshov University, in general, covers all the aspects of EFL teaching in Belarusian higher educational establishments. The presented educational and methodological support helps students to acquire the norms of clear pronunciation, grammatical system and vocabulary of the English language. The overall structure of the developed textbooks, the topics included and the exercises provided correlate with the programme documentation and follow the communicative approach. The intention to use reallike situations and explore all four language skills in an integrated way is the key purpose. The textbooks can be recommended both for in-class work and for students' independent study of the proposed material. The knowledge gained during the study of a foreign language can be applied in the yearly paper where the student demonstrates all the obtained abilities and skills.

\section{References}

1. Tikhonova E., Raitskaya L. (2018) An Overview of trends and challenges in higher education on the worldwide research agenda. Journal of Language and Education, 4(4), 4-7.

2. Ibna Seraj P.M., Hadina H. (2021) A Systematic overview of issues for developing EFL learners' oral English communication skills. Journal of Language and Education, 7(1), 229-240.

3. Василенко Е.Н., Иванов Е.Е., Шестернева А.Н. (2020) Английский язык. Развитие навыков устной и письменной речи = English. Developing Speaking and Writing Skills: учебное пособие: в 2 ч. Могилев: МГУ имени А. А. Кулешова. Ч. 1. 348 с.

4. Василенко Е.Н., Иванов Е.Е., Шестернева А.Н. (2020) Английский язык. Развитие навыков устной и письменной речи = English. Developing Speaking and Writing Skills: учебное пособие: в 2 ч. Могилев: МГУ имени А. А. Кулешова. Ч. 2. 232 с.

5. Голякевич Н.Д., Зубрий С.П., Иванов Е.Е. (2019) Практическая грамматика английского языка: морфология = Practical English Grammar: Morphology: учебное пособие. Минск: РИВШ, 2019. 268 с. 
6. Василенко Е.Н., Глуханько Л.В., Рингевич В.В., Шестернева А.Н. (2018) Основной иностранный язык $=$ Speech practice: Sport = Практика речи: спорт: учебно-методическое пособие. Могилев: МГУ имени А. А. Кулешова. 104 с.

7. Василенко Е.Н., Глуханько Л.В., Шестернева А.Н. (2018) Практика речи: Болезни XXI в. = Speech practice: 21st Century Diseases: учеб.-метод. пособие. Могилев: МГУ имени А. А. Кулешова. 88 с.

8. Василенко Е.Н., Глуханько Л.В., Шестернева А.Н. (2018) Практика речи: Забота о здоровье = Speech practice: Healthcare: учеб.-метод. пособие. Могилев: МГУ имени А. А. Кулешова. 96 с.

9. Василенко Е.Н., Шестернева А.Н. (2018) Практика речи: Личность = Speech practice: Person and Personality: учеб.-метод. пособие. Могилев: МГУ имени А. А. Кулешова. 148 с.

10. Василенко Е.Н., Рингевич В.В., Шестернева А.Н. (2019) Практика речи: Отдых и досуг. Путешествия = Speech practice: Recreation \& Leisure. Travelling: учебно-методическое пособие. Могилев: МГУ имени А. А. Кулешова. 108 с.

11. Василенко Е.Н., Глуханько Л.В., Шестернева А.Н. (2019) Практика речи: Работа = Speech practice: Jobs: учеб.-метод. пособие. Могилев: МГУ имени А. А. Кулешова. 104 с.

12. Василенко Е.Н., Рингевич В.В., Шестернева А.Н. (2019) Практика речи: У карты мира. Городская жизнь = Speech practice: World Map. City Life: учеб.-метод. пособие. Могилев: МГУ имени А. А. Кулешова. 132 с.

13. Глуханько Л.В. (2020) Основной иностранный язык. Уровень 1. Практика речи. Лексика: правильный выбор слова = English Speech Practice. Level 1. Lexical Meaning: Choosing the Rigt Word: учебнометодическое пособие. Могилев: МГУ имени А. А. Кулешова. 68 с.

14. Глуханько Л.В. (2021) Основной иностранный язык. Уровень 2. Практика речи. Лексика: правильный выбор слова = English Speech Practice. Level 2 Lexical Meaning: Choosing the Right Word: учебнометодическое пособие. Могилев: МГУ имени А. А. Кулешова. 64 с.

15. Глуханько Л.В. (2020) Основной иностранный язык. Уровень 3. Практика речи. Лексика: правильный выбор слова = English Speech Practice. Level 3. Lexical Meaning: Choosing the Righht Word: учебно-методическое пособие. Могилев: МГУ имени А. А. Кулешова. 64 с.

16. Глуханько Л.В., Голякевич Н.Д., Зубрий С.П., Иванов Е.Е. (2017) Практическая грамматика английского языка: неличные формы глагола = Practical English Grammar: Verbals: учеб.-метод. пособие. Могилев: МГУ имени А. А. Кулешова. 168 с.

17. Голякевич Н.Д., Зубрий С.П. (2016) Практическая грамматика английского языка: морфология: учеб.-метод. пособие. Могилев: МГУ имени А. А. Кулешова. 228 с.

18. Голякевич Н.Д., Зубрий С.П. (2019) Практическая грамматика английского языка: элементарный уровень = Practical English Grammar: Elementary Level: учебно-методическое пособие. Могилев: МГУ имени А. А. Кулешова. 68 с.

19. Иванов Е.Е., Петрушевская Ю.А. (2017) Курсовые работы по языкознанию (фразеология, паремиология, афористика английского языка): учеб.-метод. пособие. Могилев: МГУ имени А. А. Кулешова. $204 \mathrm{c}$.

20. Иванов Е.Е., Петрушевская Ю.А. (2019) Происхождение и история английских пословиц = Тhе Etymology and History of English Proverbs: учебно-методическое пособие. Могилев: МГУ имени А. А. Кулешова. 80 с.

21. Книга Ю.А. (2019) Практика речи: Жилье = Speech practice: Housing and accommodation: учебнометодическое пособие. Могилев: МГУ имени А. А. Кулешова. 76 с.

22. Петрушевская Ю.А. (2019) Основной иностранный язык. Уровень 1: Практическая фонетика: вводно-коррективный курс $=$ First foreign language. Level 1: Practical Phonetics: Introductory Course: учебнометодическое пособие. Могилев: МГУ имени А. А. Кулешова. 116 с.

23. Якубова В.Ю. (2019) Практика речи: Питание = Speech Practice: Food and Meals: учебнометодическое пособие. Могилев: МГУ имени А. А. Кулешова. 116 с.

24. Adil M. (2020) Exploring the Role of Translation in Communicative Language Teaching or the Communicative Approach. SAGE Open, 10(2), 1-10. DOI: 10.1177/2158244020924403.

25. Winch J. (2019) Does communicative language teaching help develop students' competence in thinking critically? Journal of Language and Education, 5(2), 112-122.

\section{References}

1. Tikhonova E., Raitskaya L. (2018) An Overview of trends and challenges in higher education on the worldwide research agenda. Journal of Language and Education, 4(4), 4-7.

2. Ibna Seraj P.M., Hadina H. (2021) A Systematic overview of issues for developing EFL learners' oral English communication skills. Journal of Language and Education, 7(1), 229-240.

3. Vasilenko E.N., Ivanov E.E., Shesterneva A.N. (2020) Angliyskiy yazyk. Razvitie navykov ustnoy i pis'mennoy rechi. [Developing Speaking and Writing Skills: uchebnoe posobie: v 2 ch.] Mogilev: MGU imeni A. A. Kuleshova. Ch. 1. 348 s. (in Russ.) 
4. Vasilenko E.N., Ivanov E.E., Shesterneva A.N. (2020) Angliyskiy yazyk. Razvitie navykov ustnoy i pis'mennoy rechi. [Developing Speaking and Writing Skills: uchebnoe posobie: v 2 ch.] Mogilev: MGU imeni A. A. Kuleshova. Ch. 2. 232 s. (in Russ.)

5. Golyakevich N.D., Zubriy S.P., Ivanov E.E. (2019) Prakticheskaya grammatika angliyskogo yazyka: morfologiya. [English Grammar: Morphology: uchebnoe posobie]. Minsk: RIVSh, 2019. 268 s. (in Russ.)

6. Vasilenko E.N., Glukhan'ko L.V., Ringevich V.V., Shesterneva A.N. (2018) Osnovnoy inostrannyy yazyk. Praktika rechi: sport: uchebno-metodicheskoe posobie. [The main foreign language. Speech practice: Sport: an educational and methodological guide]. Mogilev: MGU imeni A. A. Kuleshova. 104 s. (in Russ.)

7. Vasilenko E.N., Glukhan'ko L.V., Shesterneva A.N. (2018) Praktika rechi: Bolezni XXI v.: ucheb.metod. posobie. [Speech practice: 21 st Century Diseases: an educational and methodological guide]. Mogilev: MGU imeni A. A. Kuleshova. 88 s. (in Russ.)

8. Vasilenko E.N., Glukhan'ko L.V., Shesterneva A.N. (2018) Praktika rechi: Zabota o zdorov'e = Speech practice: Healthcare: ucheb.-metod. posobie. Mogilev: MGU imeni A. A. Kuleshova. 96 s. (in Russ.)

9. Vasilenko E.N., Shesterneva A.N. (2018) Praktika rechi: Lichnost' = Speech practice: Person and Personality: ucheb.-metod. posobie. Mogilev: MGU imeni A. A. Kuleshova. 148 s. (in Russ.)

10. Vasilenko E.N., Ringevich V.V., Shesterneva A.N. (2019) Praktika rechi: Otdykh i dosug. Puteshestviya $=$ Speech practice: Recreation \& Leisure. Travelling: uchebno-metodicheskoe posobie. Mogilev: MGU imeni A. A. Kuleshova. 108 s. (in Russ.)

11. Vasilenko E.N., Glukhan'ko L.V., Shesterneva A.N. (2019) Praktika rechi: Rabota = Speech practice: Jobs: ucheb.-metod. posobie. Mogilev: MGU imeni A. A. Kuleshova. 104 s.

12. Vasilenko E.N., Ringevich V.V., Shesterneva A.N. (2019) Praktika rechi: U karty mira. Gorodskaya zhizn' = Speech practice: World Map. City Life: ucheb.-metod. posobie. Mogilev: MGU imeni A. A. Kuleshova. 132 s. (in Russ.)

13. Glukhan'ko L.V. (2020) Osnovnoy inostrannyy yazyk. Uroven' 1. Praktika rechi. Leksika: pravil'nyy vybor slova = English Speech Practice. Level 1. Lexical Meaning: Choosing the Right Word: uchebnometodicheskoe posobie. Mogilev: MGU imeni A. A. Kuleshova. 68 s. (in Russ.)

14. Glukhan'ko L.V. (2021) Osnovnoy inostrannyy yazyk. Uroven' 2. Praktika rechi. Leksika: pravil'nyy vybor slova $=$ English Speech Practice. Level 2 Lexical Meaning: Choosing the Right Word: uchebnometodicheskoe posobie. Mogilev: MGU imeni A. A. Kuleshova. 64 s. (in Russ.)

15. Glukhan'ko L.V. (2020) Osnovnoy inostrannyy yazyk. Uroven' 3. Praktika rechi. Leksika: pravil'nyy vybor slova $=$ English Speech Practice. Level 3. Lexical Meaning: Choosing the Right Word: uchebnometodicheskoe posobie. Mogilev: MGU imeni A. A. Kuleshova. 64 s. (in Russ.)

16. Glukhan'ko L.V., Golyakevich N.D., Zubriy S.P., Ivanov E.E. (2017) Prakticheskaya grammatika angliyskogo yazyka: nelichnye formy glagola = Practical English Grammar: Verbals: ucheb.-metod. posobie. Mogilev: MGU imeni A. A. Kuleshova. 168 s. (in Russ.)

17. Golyakevich N.D., Zubriy S.P. (2016) Prakticheskaya grammatika angliyskogo yazyka: morfologiya: ucheb.-metod. posobie. Mogilev: MGU imeni A. A. Kuleshova. 228 s. (in Russ.)

18. Golyakevich N.D., Zubriy S.P. (2019) Prakticheskaya grammatika angliyskogo yazyka: elementarnyy uroven' = Practical English Grammar: Elementary Level: uchebno-metodicheskoe posobie. Mogilev: MGU imeni A. A. Kuleshova. 68 s. (in Russ.)

19. Ivanov E.E., Petrushevskaya Yu.A. (2017) Kursovye raboty po yazykoznaniyu (frazeologiya, paremiologiya, aforistika angliyskogo yazyka): ucheb.-metod. posobie. Mogilev: MGU im. A. A. Kuleshova. 204 s. (in Russ.)

20. Ivanov E.E., Petrushevskaya Yu.A. (2019) Proiskhozhdenie i istoriya angliyskikh poslovits = The Etymology and History of English Proverbs: uchebno-metodicheskoe posobie. Mogilev: MGU imeni A. A. Kuleshova. 80 s. (in Russ.)

21. Kniga Yu.A. (2019) Praktika rechi: Zhil'e = Speech practice: Housing and accommodation: uchebnometodicheskoe posobie. Mogilev: MGU imeni A. A. Kuleshova. 76 s. (in Russ.)

22. Petrushevskaya Yu.A. (2019) Osnovnoy inostrannyy yazyk. Uroven' 1: Prakticheskaya fonetika: vvodno-korrektivnyy kurs = First foreign language. Level 1: Practical Phonetics: Introductory Course: uchebnometodicheskoe posobie. Mogilev: MGU imeni A. A. Kuleshova. 116 s. (in Russ.)

23. Yakubova V.Yu. (2019) Praktika rechi: Pitanie = Speech Practice: Food and Meals: uchebnometodicheskoe posobie. Mogilev: MGU imeni A. A. Kuleshova. 116 s. (in Russ.)

24. Adil M. (2020) Exploring the Role of Translation in Communicative Language Teaching or the Communicative Approach. SAGE Open, 10(2), 1-10. DOI: 10.1177/2158244020924403.

25. Winch J. (2019) Does communicative language teaching help develop students' competence in thinking critically? Journal of Language and Education, 5(2), 112-122.

Учебно-методическое обеспечение преподавания английского языка как основного иностранного для студентов высших учебных заведений Республики Беларусь 


\section{П.А. Губич*, К.О. Климуть}

Могилевский государственный университет имени А.А. Кулешова, г. Могилев, Беларусь

*Автор, ответственный за переписку: gubichpolina@gmail.com

В статье рассматривается актуальная проблема обеспечения преподавания английского языка как основного иностранного для студентов языковых специальностей в белорусских высших учебных заведениях. В статье представлен обзор разработанных преподавателями кафедры теоретической и прикладной лингвистики Могилевского государственного университета имени А.А. Кулешова методических пособий по дисциплине «Основной иностранный язык» для специальности 1-21 0506 «Романо-германская филология». Дается описание структурных особенностей учебно-методических пособий, их тематическое и содержательное наполнение. Обозреваются различные типы упражнений (языковые, условно-речевые, речевые). Приводятся примеры упражнений, используемых в различных разделах и секциях учебно-методических пособий (Topical Vocabulary, Lead-in, Focus on Reading, Focus on Vocabulary, Focus on Idioms, Focus on Listening, Focus on Speaking, Focus on Writing, Project и др.). Делаются выводы о важности подготовки учебно-методических пособий для обеспечения преподавания английского языка как основного иностранного для студентов языковых специальностей в белорусских высших учебных заведениях в соответствии с коммуникативным подходом и программной документацией.

Ключевые слова: преподавание английского языка как основного иностранного, учебное пособие по английскому языку, английский язык, основной иностранный язык, высшее образование в Беларуси.

\section{Ағылшын тілін оқытуды оқу-әдістемелік қамтамасыз ету \\ Беларусь Республикасы жоғары оку орындарының студенттері үшін негізгі шетелдік ретінде}

\section{П.А. Губич*, К.О. Климуть}

А.А. Кулешов атындағы Могилев мемлекеттік университеті, Могилев қ., Беларусь

* Автор-тілші: gubichpolina@gmail.com

Мақалада Беларуссияның жоғары оқу орындарында тілдік мамандықтар студенттері үшін негізгі шет тілі ретінде ағылшын тілін оқытуды қамтамасыз етудің өзекті мәселесі қарастырылады. Мақалада А.А.Кулешов атындағы Могилев мемлекеттік университетінің Теориялық және қолданбалы лингвистика кафедрасының оқытушылары әзірлеген 1-21 0506 "Роман-герман филологиясы" мамандығына арналған "Негізгі шет тілі" пәні бойынша әдістемелік құралдарға шолу жасалды. Оку-әдістемелік құралдардың құрылымдық ерекшеліктері, олардың тақырыптық және мазмұны сипатталады. Жаттығулардың әр түрі қарастырылады (тілдік, шартты сөйлеу, сөйлеу). Оқу-әдістемелік құралдардың (Topical Vocabulary, Lead-in, Focus on Reading, Focus on Vocabulary, Focus on Idioms, Focus on Listening, Focus on Speaking, Focus on Writing, Project және т.б.) әр түрлі бөлімдері мен секцияларында пайдаланылатын жаттығулардың мысалдары келтіріледі. Коммуникативтік тәсіл мен бағдарламалық құжаттамаға сәйкес Беларуссияның жоғары оқу орындарында тілдік мамандықтар студенттері үшін негізгі шет тілі ретінде ағылшын тілін оқытуды қамтамасыз ету үшін оқу-әдістемелік құралдарды дайындаудың маңыздылығы туралы қорытынды жасалады.

Түйін сөздер: ағылшын тілін негізгі шет тілі ретінде оқыту, ағылшын тілі бойынша оқу құралы, ағылшын тілі, негізгі шет тілі, Беларуссиядағы жоғары білім.

\section{INFORMATION ABOUT THE AUTHORS}

Polina A. Gubich, lecturer of the Department of Theoretical and Applied Linguistics, Mogilev State A. Kuleshov University. Address: Belarus, Mogilev, 212022, 1-421. Kosmonavtov street; gubichpolina@gmail.com

Kristina O. Klimut, lecturer of the Department of Theoretical and Applied Linguistics, Mogilev State A. Kuleshov University. Address: Belarus, Mogilev, 212022, 1-421. Kosmonavtov street; kristya_klm@mail.ru

\section{ИНФОРМАЦИЯ ОБ АВТОРАХ}


Губич Полина Андреевна, преподаватель кафедры теоретической и прикладной лингвистики, Могилевский государственный университет имени А. А. Кулешова. Адрес: Республика Беларусь, г. Могилев, 212022, ул. Космонавтов, 1-421; gubichpolina@gmail.com

Климуть Кристина Олеговна, преподаватель кафедры теоретической и прикладной лингвистики, Могилевский государственный университет имени А. А. Кулешова. Адрес: Республика Беларусь, г. Могилев, 212022, ул. Космонавтов, 1-421; kristya_klm@mail.ru

\section{АВТОРЛАР ТУРАЛЫ АҚПАРАТ}

Губич Полина Андреевна, теориялық және қолданбалы лингвистика кафедрасының оқытушысы, А.А. Кулешов атындағы Могилев мемлекеттік университеті. Мекенжайы: Беларусь Республикасы, Могилев қаласы, 212022, Космонавтов көшесі, 1-421; gubichpolina@gmail.com

Климуть Кристина Олеговна, теориялық және қолданбалы лингвистика кафедрасының оқытушысы, А. А. Кулешов атындағы Могилев мемлекеттік университеті. Мекенжайы: Беларусь Республикасы, Могилев қаласы, 212022, Космонавтов көшесі, 1-421; kristya_klm@mail.ru

Редакцияға түсті / Поступила в редакцию / Received 15.09.2021

Жариялауға қабылданды / Принята к публикации / Accepted 28.09.2021 